\title{
Perbandingan Sensasi Nyeri 48 Jam dan 42 Hari Pascasalin Menggunakan Benang Chromic Catgut dengan Fast Absorbing Polyglactin 910
}

\author{
Benny Hasan Purwara, M Rizkar Arev Sukarsa, R M Sonny Sasotya, Eppy Darmadi Achmad \\ Departemen Obstetri dan Ginekologi \\ Fakultas Kedokteran Universitas Padjadjaran-Rumah Sakit Dr. Hasan Sadikin, Bandung
}

\begin{abstract}
Abstrak
Nyeri perineum akibat robekan yang terjadi pada saat persalinan dapat dirasakan segera setelah melahirkan atau beberapa bulan kemudian, sehingga menyebabkan dispareunia. Episiotomi sebagai profilaktik untuk melindungi integritas dasar panggul merupakan insisi bedah yang lurus dan rapi akan menggantikan laserasi kasar. Sensasi nyeri akibat penjahitan luka episiotomi dapat dikurangi dengan menggunakan benang yang cepat diabsorbsi. Tujuan penelitian ini untuk membandingkan sensasi nyeri perineum pascapenjahitan luka episiotomi menggunakan benang chromic catgut dengan fast absorbing polyglactin 910 terhadap nyeri perineum 48 jam dan 42 hari pascasalin. Penelitian ini dilakukan di Departemen Obstetri dan Ginekologi FK Universitas Padjadjaran-RS Dr. Hasan Sadikin Bandung periode Desember 2009-Maret 2010. Penilaian nyeri menggunakan visual analog scale (VAS) yang dilakukan 48 jam dan 42 hari pascasalin. Lima puluh dari 100 subjek penelitian dilakukan penjahitan dengan benang chromic catgut dan 50 subjek menggunakan benang fast absorbing polyglactin 910. Analisis uji chi-kuadrat 48 jam pascasalin, didapatkan hasil tidak ada perbedaan bermakna pada penggunaan kedua benang tersebut terhadap nyeri perineum $(\mathrm{p}=0,645)$. Analisis 42 hari pascasalin didapatkan perbedaan bermakna $(\mathrm{p}<0,001)$, kejadian bebas nyeri perineum lebih baik dengan penjahitan menggunakan benang fast absorbing polyglactin 910 (46 kasus atau $92 \%$ ) dibandingkan dengan pemakaian benang chromic catgut (29 kasus atau 58\%). Simpulan, penjahitan luka perineum menggunakan benang fast absorbing polyglactin 910 memberikan kejadian bebas nyeri perineum yang lebih baik dibandingkan dengan benang chromic catgut pada 42 hari pascasalin. [MKB. 2011;43(2):89-92].
\end{abstract}

Kata kunci: Chromic catgut, fast absorbing polyglactin 910, nyeri perineum

\section{Comparative Study of Pain Sensation at 48 hours and 42 Days Postpartum Using Chromic Catgut and Polyglactin 910}

\begin{abstract}
Perineal pain due to tears that occur during delivery can be felt immediately after birth or several months later, causing dyspareunia. Episiotomy as a prophylactic to protect the integrity of the pelvic floor is a straight and neat surgical incision will replace rough lacerations. Pain sensation due to episiotomy wound suturing can be reduced by using thread that quickly absorbed. The purpose of this study was to compare perineal pain sensation after suturing episiotomy wound using chromic catgut with using fast absorbing polyglactin 910 . The perineal pain of both groups were evaluated 48 hours and 42 days post episiotomy using visual analog scale (VAS). This study was conducted at the Obstetrics and Gynecology Department, Faculty of Medicine Padjadjaran University/Dr. Hasan Sadikin Hospital period December 2009-March 2010. Fifty out of 100 subjects were sutured using chromic catgut and 50 were using fast-absorbing polyglactin 910. Chi-square test analysis at 48 hours postpartum, showed no significant perineal pain difference $(\mathrm{p}=0.645)$ of both groups but at 42 days the analysis showed a significant difference $(p<0.001)$ between both groups, incidence of perineal pain free better with fast absorbing sutures using polyglactin 910 (46 cases or $92 \%$ ) compared with the use of chromic catgut (29 cases or 58\%). In conclusion, suturing perineal wound using fast-absorbing polyglactin 910 provide free events perineal pain better than chromic catgut in 42 days. [MKB. 2011;43(2):89-92].
\end{abstract}

Key words: Chromic catgut, fast-absorbing polyglactin 910, perineal pain

Korespondensi: Benny Hasan P, dr., Sp.OG(K), Departemen Obstetri dan Ginekologi Fakultas Kedokteran Unpad-Rumah Sakit Dr. Hasan Sadikin, jalan Pasteur 38 Bandung, mobile 08122011778, faks (022) 2039086, e-mail: bennyhp3042@gmail. com 


\section{Pendahuluan}

Robekan perineum dapat dihindari atau dikurangi saat persalinan dengan cara memperlambat keluarnya kepala janin saat melalui perineum. ${ }^{1}$ Sebanyak $85 \%$ wanita yang melahirkan spontan mengalami trauma/ruptur perineum. Sebagian besar wanita tersebut akan mengalami nyeri perineum yang terjadi tidak hanya segera setelah melahirkan, tetapi juga beberapa bulan kemudian. Sekitar 20\% dispareunia menetap dan menjadi masalah yang berkepanjangan. ${ }^{2,3}$

Episiotomi adalah insisi perineum untuk memperlebar ruang jalan lahir, sehingga memudahkan kelahiran anak dan merupakan tindakan yang paling sering dilakukan dalam kebidanan. Alasannya adalah tindakan episiotomi dengan insisi bedah yang lurus dan rapi ini menggantikan laserasi kasar yang sering terjadi. ${ }^{1,3,4}$

Indikasi episiotomi selain sebagai profilaktik untuk melindungi integritas dasar panggul, juga dilakukan untuk melindungi janin, seperti bayi prematur, bayi besar, posisi abnormal, atau persalinan per vaginam yang sulit (presentasi bokong, ekstraksi forseps, ekstraksi vakum, distosia bahu). ${ }^{1,3,5}$

Sensasi nyeri dari jalan lahir dihantar ke medula spinalis melalui saraf, informasinya diberikan dalam bentuk impuls listrik. Medula spinalis berfungsi sebagai penghantar impuls listrik antara saraf perifer dan otak. Impuls yang mengandung informasi nyeri tiba di medula spinalis melalui saraf, kemudian ditransfer melalui nervus intermedius atau neuron ke otak. Sebelum transmisi nyeri mencapai otak, neuron-neuron nyeri atau sel target (sel T) harus distimulasi. Sel target berada dalam keadaan eksitasi, mengeluarkan impuls nyeri dan dipengaruhi oleh substansi kimiawi yang dilepaskan oleh ujung saraf yang dikenal sebagai neurotransmit. ${ }^{6}$

Chromic catgut merupakan benang natural bersifat dapat diserap (absorbable) dengan profil absorbsi 90-110 hari. Tujuh hari setelah penjahitan menggunakan benang chromic catgut, maka di sekeliling luka timbul peradangan kronik sedang, ditandai dengan munculnya makrofag dan limfosit. Reaksi ini dihasilkan selain oleh trauma nonspesifik akibat "implantasi" benang, juga disebabkan karena proses antigenisitas yang ditimbulkan oleh protein asing bahan dasar chromic catgut. Duapuluh delapan hari setelah penjahitan dengan benang chromic catgut, maka di sekeliling tempat jahitan akan timbul peradangan kronik ringan dengan jaringan otot di sekitarnya tetap normal. ${ }^{7,8}$

Benang fast absorbing polyglactin 910 mempunyai kelebihan, yaitu kekuatan regangan benang (tensile strength) akan hilang pada hari ke-10 sampai hari ke-14 dan selesai diabsorbsi pada hari ke-42, sehingga tidak menimbulkan masalah sebagai akibat reabsorbsi benang yang lama. Tujuh hari setelah penjahitan dengan benang fast absorbing polyglactin 910, maka di sekeliling luka akan timbul peradangan kronik ringan yang ditandai dengan munculnya makrofag dan limfosit. Reaksi tersebut adalah akibat trauma nonspesifik karena "implantasi" benang dalam jaringan., ${ }^{7,8}$

Duapuluh delapan hari setelah penjahitan dengan benang fast absorbing polyglactin 910 timbul reaksi antibodi yang ringan, ditandai munculnya peradangan kronik dan terdapat foreign body giant cells di antara filamen benang, tetapi jaringan otot di sekitarnya tetap normal. 7,8

Belum diketahui apakah terdapat perbedaan sensasi nyeri perineum pascasalin menggunakan benang chromic catgut dibandingkan dengan benang fast absorbing polyglactin 910. Tujuan penelitian ini untuk membandingkan sensasi nyeri perineum pascapenjahitan luka episiotomi menggunakan benang chromic catgut dengan fast absorbing polyglactin 910 terhadap nyeri perineum 48 jam dan 42 hari pascasalin.

\section{Metode}

Penelitian dilakukan pada bulan Desember 2009Maret 2010 di Departemen Obstetri dan Ginekologi Rumah Sakit Umum Dr. Hasan Sadikin Bandung. Subjek adalah wanita pascasalin spontan dengan episiotomi (medial maupun mediolateral) ataupun yang mengalami ruptur perineum tingkat II persalinan secara per vaginam. Wanita pascasalin yang masuk kriteria inklusi akan tetapi dalam perjalanan penelitian jahitan perineum terlepas, dikeluarkan dari penelitian. Diagnosis serta penjahitan dilakukan oleh dokter yang telah mendapat pelatihan penjahitan luka perineum.

Penelitian dilakukan secara acak tersamar tunggal (single blind) terhadap wanita pascasalin spontan dengan episiotomi (medial maupun mediolateral) ataupun yang mengalami ruptur perineum tingkat II yang dijahit dengan benang chromic catgut yang dibandingkan dengan fast absorbing polyglactin 910 untuk menilai sensasi nyeri perineum pascasalin.

Alokasi subjek penelitian ke dalam kelompok perlakuan dilakukan secara random blok permutasi, yaitu suatu pengelompokan subjek penelitian guna mendapatkan jumlah yang seimbang untuk setiap perlakuan.

Besar sampel ditentukan atas dasar penelitian Leroux dan Bujold, ${ }^{7}$ angka kejadian hilangnya nyeri perineum pada penjahitan dengan benang chromic catgut sebesar 0,42 dan pada benang fast absorbing polyglactin 910 adalah 0,66. Ditetapkan taraf kepercayaan (confidence interval) $95 \%$ dan 
kekuatan uji (power test) 80\% dengan memakai rumus besar sampel untuk menguji perbedaan 2 proporsi.

Batasan dan penilaian kriteria di atas adalah: 1) nyeri pascasalin adalah rasa sakit yang dirasakan oleh ibu pascasalin dinyatakan dengan nilai visual analog scale (VAS) 1 sampai 10,2) visual analog scale adalah penilaian nyeri pascasalin berdasarkan intensitas nyeri yang dirasakan ibu dinyatakan dengan angka 1-10, yaitu nyeri derajat 1 (nyeri ringan) bila nilai VAS 0-3, nyeri derajat 2 (nyeri sedang) bila nilai VAS 4-6, dan nyeri derajat 3 (nyeri berat) bila nilai VAS 7-10.

Penderita yang memenuhi kriteria inklusi dan tidak termasuk kriteria eksklusi dilakukan anamnesis dan pemeriksaan fisis, kemudian secara random blok permutasi dibagi menjadi dua kelompok, yaitu kelompok perlakuan dengan benang chromic catgut dan mempergunakan benang fast absorbing polyglactin 910.

Penilaian nyeri pascasalin dilakukan 2 kali, yakni pada 48 jam pascasalin oleh penderita dengan meminta melingkari salah satu angka sesuai dengan derajat nyeri yang dirasakan dan pada 42 hari pascasalin dengan metode yang sama.

Data yang diperoleh dicatat kemudian diolah dengan program SPSS versi 13.0 for Windows. Untuk mengetahui perbedaan data kategorik kedua kelompok digunakan uji chi-kuadrat, sedangkan untuk mengetahui perbedaan dua nilai tengah digunakan uji Mann Whitney. Kemaknaan ditentukan berdasarkan nilai $\mathrm{p}<0,05$.

\section{Hasil}

Selama periode penelitian, didapatkan 100 penderita pascasalin yang memenuhi kriteria inklusi, sebanyak 50 orang setelah dilakukan randomisasi termasuk dalam kelompok perlakuan dengan benang chromic catgut dan 50 orang lagi termasuk dalam kelompok perlakuan mempergunakan fast absorbing polyglactin 910.

Tabel menggambarkan derajat VAS pada 48 jam pada kedua kelompok penelitian tidak menunjukkan perbedaan yang bermakna $(\mathrm{p}>0,05)$, sedangkan derajat VAS pada 42 hari menunjukkan perbedaan bermakna $(p<0,001)$, yaitu derajat nyeri pada kelompok fast absorbing lebih ringan dibandingkan dengan kelompok chromic cat gut.

\section{Pembahasan}

Karakteristik subjek penelitian pada kelompok dengan jahitan menggunakan benang chromic catgut dan benang fast absorbing polyglactin 910 berdasarkan usia tidak didapatkan perbedaan yang bermakna antara kedua kelompok. Kelompok usia rerata subjek penelitian adalah 25,1 tahun pada kelompok penjahitan luka perineum

Tabel Karakteristik Subjek Penelitian Periode Bulan Desember 2009 sampai Maret 2010

\begin{tabular}{|c|c|c|c|}
\hline \multirow[b]{2}{*}{ Karakteristik } & \multicolumn{2}{|c|}{ Kelompok } & \multirow[b]{2}{*}{ Kemaknaan } \\
\hline & $\begin{array}{c}\text { Fast Absorbing } \\
\text { Polyglactin } 910 \\
(\mathrm{n}=50)\end{array}$ & $\begin{array}{l}\text { Chromic Catgut } \\
\quad(\mathrm{n}=\mathbf{5 0})\end{array}$ & \\
\hline \multicolumn{4}{|l|}{ Jenis tindakan } \\
\hline Episiotomi & 16 & 13 & $x=0,437$ \\
\hline Ruptur perineum tingkat II & 34 & 37 & $\mathrm{p}=0,508$ \\
\hline \multicolumn{4}{|l|}{ Usia (tahun) } \\
\hline$X(S D)$ & $25,3(4,4)$ & $25,1(4,8)$ & $Z_{\mathrm{MW}}=0,290$ \\
\hline Median & 24 & 24 & $\mathrm{p}=0,770$ \\
\hline Rentang & $18-34$ & $17-36$ & \\
\hline \multicolumn{4}{|l|}{ VAS (48 jam) } \\
\hline Normal & 4 & 2 & $x^{2}=0,878$ \\
\hline Ringan & 44 & 45 & $\mathrm{p}=0,645$ \\
\hline Sedang & 2 & 3 & \\
\hline \multicolumn{4}{|l|}{ VAS (42 hari) } \\
\hline Normal & 46 & 28 & $x^{2}=16,84$ \\
\hline Ringan & 4 & 22 & $\mathrm{p}<0,001$ \\
\hline
\end{tabular}

Keterangan: $x^{2}=$ uji chi-kuadrat; $\mathrm{Z}_{\mathrm{M}-\mathrm{w}}=$ Uji Mann-Whitney 
mempergunakan benang chromic catgut dan 25,3 tahun pada kelompok penjahitan luka perineum dengan benang fast absorbing polyglactin 910. Dengan demikian, dapat dikatakan bahwa subjek penelitian homogen dan layak untuk dibandingkan. Perbandingan jenis tindakan/ luka secara statistik dinyatakan tidak berbeda bermakna $(\mathrm{p}>0,05)$.

Derajat VAS pada 48 jam pascasalin secara statistik dinyatakan perbedaannya tidak bermakna $(p>0,05)$. Leroux dan Bujold 7 yang melakukan penelitian serupa juga tidak menemukan perbedaan sensasi nyeri yang bermakna pada penjahitan luka perineum dengan benang chromic catgut maupun penjahitan luka perineum dengan benang fast absorbing polyglactin 910 pada 48 jam pascasalin.

Penelitian yang dilakukan oleh Greenberg $\mathrm{dkk}^{8}$ pada 1.361 wanita pascasalin menunjukkan hasil yang berbeda, yaitu pada 48 jam pascasalin nyeri perineum didapatkan lebih sedikit pada wanita yang mendapat jahitan dengan benang fast absorbing polyglactin 910 dibandingkan dengan benang chromic catgut.

Pada 42 hari pascasalin perbedaan derajat VAS sangat bermakna $(p<0,001)$. Leroux dan Bujold ${ }^{7}$ juga menemukan perbedaan yang bermakna pada penjahitan luka perineum dengan benang chromic catgut dibandingkan dengan penjahitan luka perineum dengan benang fast absorbing polyglactin 910 pada 42 hari pascasalin.

McElhinney dkk. ${ }^{9}$ mempublikasikan hasil penelitiannya yang membandingkan efektivitas benang standard polyglactin 910 dengan benang fast absorbing polyglactin 910 terhadap nyeri perineum pascasalin. Mereka menyatakan bahwa penjahitan luka perineum dengan benang fast absorbing polyglactin 910 pada wanita pascasalin, 42 hari pascasalin menunjukkan angka kejadian dispareunia yang lebih sedikit.

Kettle dkk. ${ }^{10}$ juga mencoba membandingkan efektivitas benang standard polyglactin 910 dengan fast absorbing polyglactin 910 terhadap nyeri perineum pascasalin pada 1.542 wanita pascasalin menyatakan bahwa tidak ada perbedaan yang signifikan terhadap kejadian nyeri perineum pada 10 hari pascasalin dan dispareunia pada 3 bulan pascasalin; hanya saja evaluasi nyeri perineum pada 42 hari pascasalin tidak dilakukan.

Simpulan, tidak terdapat perbedaan derajat nyeri perineum 48 jam pascasalin pada penjahitan luka perineum mempergunakan benang chromic catgut maupun benang fast absorbing polyglactin 910. Penjahitan luka perineum menggunakan benang fast absorbing polyglactin 910 memberikan kejadian bebas nyeri perineum yang lebih baik dibandingkan dengan benang chromic catgut pada 42 hari pascasalin.

\section{Daftar Pustaka}

1. Wiknjosastro $\mathrm{H}$, Saifuddin $\mathrm{AB}$, Rachimhadhi T. Ilmu kebidanan. Edisi ke3. Jakarta: Yayasan Bina Pustaka Sarwono Prawirohardjo; 1999.

2. Nichols CM, Lamb EH, Ramakrishnan V. Differences in outcomes after third-versus fourth-degree perineal laceration repair: a prospective study. Am J Obstet Gynecol. 2005; 193:530-6.

3. Clemons JL, Towers GD, McClure GB. Decreased anal spincter lacerations associated with restrictive episiotomy use. Am J Obstet Gynecol. 2005;192(5):1620-5.

4. Hudelist G, Gelle'n J, Singer C. Factors predicting severe perineal trauma during childbirth: role of forceps delivery routinely combined with mediolateral episiotomy. Am J Obstet Gynecol. 2005;192(3):975-81.

5. Tanra AH. Konsep baru pengelolaan nyeri. Dalam: Soerasdi E, Adipraja K, Bisri T, penyunting. Anestesiologi di Indonesia menjelang era global. Bandung: Bagian Anestesiologi dan Reanimasi Fakultas Kedokteran Universitas Padjadjaran; 2000. hlm. 141-9.

6. Luck AM, Galvin SL, Theofrastous JP. Suture erosion and wound dehiscense with permanent versus absorbable suture in reconstructive posterior vaginal surgery. Am J Obstet Gynecol. 2005;192(5):1626-9.

7. Leroux N, Bujold E. Impact of chromic catgut versus polyglactin 910 versus fastabsorbing polyglactin 910 suture for perineal repair: a randomized, controlled trial. Am J Obstet Gynecol. 2005;192(5):1585-90.

8. Greenberg JA, Lieberman E, Cohen AP, Ecker JL. Randomized comparison of chromic versus fast-absorbing polyglactin 910 for postpartum perineal repair. Obstet Gynecol. 2004;103:1308-13.

9. McElhinney BR, Glenn DR, Dornan G, Harper MA. Episiotomy repair: vicryl versus vicryl rapide. Ulster Med J. 2000;69:27-9.

10. Kettle C, Hills RK, Jones P, Darby L, Gray R, Johanson R. Continuous versus interrupted perineal repair with standard or rapidly absorbed sutures after spontaneous vaginal birth: a randomised controlled trial. Lancet. 2002;359:2217-23. 